\title{
One-pot preparation of PS/silica hydrophobic coating by solution- casting using D-limonene as dispersing medium
}

Roderick Jesus Jude M. REGALADO graduated from De La Salle University (DLSU), Philippines with BS Biochemistry degree in 2018

Emmanuel A. PUNZALAN is currently an MS Chemistry student at De La Salle University (DLSU), Philippines. He finished his BS Chemistry degree in 2016 from DLSU.

David P. PENALOZA Jr. is an associate professor in the Chemistry Department, College of Science, De La Salle University (DLSU). His research interests focus on self-assembled systems and nanostructured materials

RoderICK Jesus JuDE M. REGALADO - Chemistry Depart
University, Manila, Philippines - roderick_regaladojr@dlsu.edu.ph

Emmanuel A. PUNZALAN - Chemistry Department, College of Science, De La Salle University, Manila, Philippines - emmanuel_punzalan@dlsu.edu.ph

David P. PENALOZA JR. " Chemistry Department, College of Science, De La Salle University, Manila, Philippines - david.penaloza.jr@dlsu.edu.ph

Érkezett: 2018. 05. 14. " Received: 14. 05. 2018. " https://doi.org/10.14382/epitoanyag-jsbcm.2019.14

\section{Abstract}

Different polystyrene (PS) coatings were prepared and optimized by dissolving PS in D-limonene and subsequent dispersion of varying amounts of different chemically modified silica nanoparticles. Among the materials prepared, a PS coating filled with silica nanoparticles organo-modified with long alkyl carbon chains results in high hydrophobicity $\left(120.8^{\circ}\right.$ as compared to bare PS coating - $67.0^{\circ}$ ) and excellent film-formation.

Keywords: PS/silica coatings, hydrophobicity, contact angle

Kulcsszavak: PS/szilícium-dioxid bevonatok, hidrofobitás, nedvesedési szög

\section{Introduction}

Highly hydrophobic coatings have been of particular interest over the last decade due to their extensive potential applications in anti-corrosion [1,2], self-cleaning [3,4], anti-fouling $[5,6]$, anti-icing $[7,8]$, and drag-reducing materials in a wide range of industries. Surfaces with water contact angles of at least $90^{\circ}$ are referred to as hydrophobic surfaces whereas surfaces with water contact angles greater than $150^{\circ}$ are referred to as superhydrophobic surfaces [9].

PS is a versatile plastic material that has found wide applications in food packaging, laboratory wares [10-13], electronics and automobile parts [11,12], etc. Due to its low cost of production, most consumer goods come in PS packaging in one form or another. This poses a serious problem to the environment as PS is shown to be relatively stable and is hard to be degraded even after 32 years as stated in a previous study [14]. Over the years, the amount of PS waste that accumulates in landfills and oceans increases. Based on global statistics, about 14 million metric tons of PS are produced each year, and only about 15 percent of that is being recycled due to cost and processing issues as PS is cheaper to produce rather than to recycle and that recycling polystyrene requires it to be contaminant free [15-18].

As a coating material, it has poor barrier characteristics to oxygen and water vapor [19], which is necessary for coating applications. However, several researchers have shown that added with inorganic fillers like silica, PS-based coating materials result in better coating materials [20-22].

Here, we prepared hydrophobic polymer coatings filled with silica nanoparticles from solution-casting using D-limonene as the dispersing medium. Highly hydrophobic coatings based on polystyrene (PS) optimized with different types of surfacemodified silica nanoparticles were prepared. In this study, one-pot method of preparation based on surface segregation phenomenon of nanoparticles on a polymer matrix was used. To make PS and silica dispersion, an environment-friendly solvent, D-limonene, was utilized. D-limonene is a natural solvent that is extracted from citrus fruits like oranges [23].

\section{Experimental methods}

\subsection{Materials}

Polystyrene (PS) (MW 350, 000) and D-limonene (>97\%) were purchased from Sigma-Aldrich Co. Three types of commercially available organo-modified nanosilica $\left(\mathrm{SiO}_{2}\right)$ particles: Aerosil R 812S, Aerosil R 816, and Aerosil R 972 were used in this study. Aerosil R 812S, Aerosil R 816, and Aerosil R 972 are silica nanoparticles chemically premodified with hexamethyldisilazane, hexadecylsilane, and dimethyldichlorosilane, respectively.

\subsection{Preparation of $\mathrm{PS} / \mathrm{SiO}_{2}$ coatings}

PS $(5.0 \mathrm{~g})$ in D-limonene $(150 \mathrm{~mL})$ was heated to $40{ }^{\circ} \mathrm{C}$ and stirred at $400 \mathrm{rpm}$ for 2 hours. Afterwards, $30 \mathrm{~mL}$ each of the polystyrene dispersion was poured into four individual clean Erlenmeyer flasks, where silica nanoparticles where added to three of the flasks and then subjected to stirring. In summary, there are four treatments considered: (1) PS - control (no silica); (2) PS/AS1 - PS/Aerosil R 812S (99:1); (3) PS/AS2 - PS/Aerosil R 816(99/1), and PS/AS3 - PS/Aerosil R 972. Each dispersion was then coated onto clean glass cover slips via solution casting and allowed to dry overnight under ambient conditions. Of the three treatments containing silica nanoparticles, the sample exhibiting highest contact angle and good film formation was then optimized by having varying $\mathrm{PS}: \mathrm{SiO}_{2}$ ratios. 


\subsection{Wetting property measurement}

The static water contact angle of each coated surface was determined by gently dropping $5 \mu \mathrm{L}$ of distilled water onto the coated surface using a micropipette. Five replicates were performed for each of the measurements. A photo of the droplet was captured immediately after the droplet was placed on the surface, and the water contact angle was calculated using Image Low-Bond Axisymmetric Drop Shape Analysis (LB-ADSA) [24,25].

\section{Results and discussion}

\subsection{Preparation of $\mathrm{PS} / \mathrm{SiO}_{2}$ coatings}

The four treatment samples: (1) PS - control (no silica); (2) PS/AS1 - PS/Aerosil R 812S (99:1); (3) PS/AS2 - PS/Aerosil R 816(99/1), and PS/AS3 - PS/Aerosil R 972 when solutioncasted on glass slides.

As shown in Fig. 1, the PS dispersion containing no silica nanoparticles formed a transparent film. PS/AS1 and PS/ AS2, both result in homogeneous dispersion of the nanosilica particles, though, not transparent as the PS film (no silica). PS/ AS3 exhibited poor homogenous film-formation, as a result of the silica particles poorly dispersed within the PS matrix.

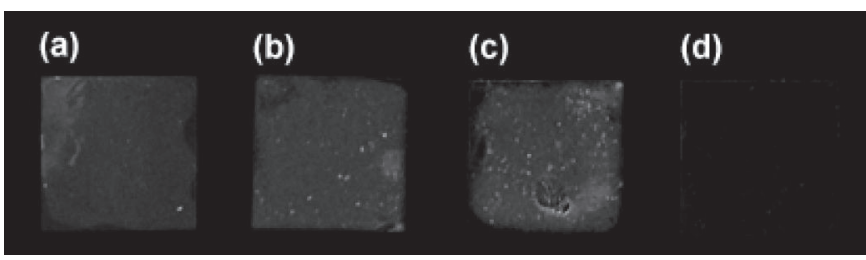

Fig. 1 Glass cover slips coated with a) PS/AS1, b) PS/AS2, c) PS/AS3 and d) PS (control)

1. ábra Üvegfedőlapok a) PS/AS1, b) PS/AS2, c) PS/AS3 és d) PS (etalon) bevonattal

The method for contact angle analysis was first calibrated by comparing the water contact angles of PS and glass used to the ones previously reported elsewhere. The average water contact angle of PS is $\sim 68^{\circ}$ while that of glass is $\sim 40^{\circ}$ [26]. Using the low-bond axisymmetric drop shape analysis (LBADSA) method [24,25], the water contact angles of PS and glass subtract were found to match previously documented data. As shown in Fig. 2, all PS films filled with nanosilica showed higher contact angle values than the bare PS coating, indicating more hydrophobic effect to the PS matrix by organomodified silica incorporation. Though PS/AS1 results to an even coating from visual inspection than PS/AS2, the latter exhibited higher contact angle $\left(\right.$ Mean $\left.=120.6^{\circ}\right)$. Among the films with incorporated silica, PS/AS3 results in lowest contact angle value and poor dispersion of the particles. Statistical analysis of all treatments showed a significant difference in the observed contact angles of the coatings.

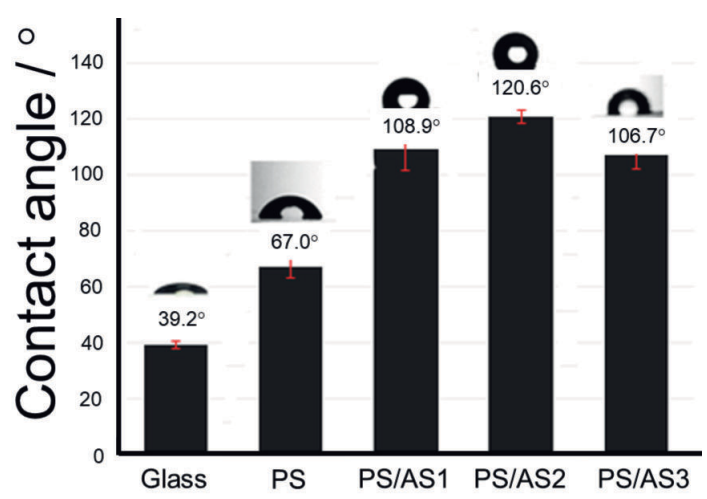

Fig. 2. Contact angle measurements of the glass substrate used and different PS coatings applied on glass

2. ábra Nedvesitési szög üvegen és különbözö PS bevonatokon

From the results of film casting and contact angle measurements, PS film modified with Aerosil R 816 exhibited homogeneously dispersed particles in a PS matrix with high hydrophobicity (high contact angle). Based on an initial PS/ silica ratio of 99/1, varying ratios of PS/Aerosil R816 were then prepared.

As expected, the non-wetting behavior of PS-AS2 improved with increasing concentration of modified silica (Fig. 3). However, at $\mathrm{SiO}_{2}$ concentration greater than $3.0 \%$ (relative to PS) decreased hydrophobicity and poor film formation were noted due to cracking brought about by particle aggregation.

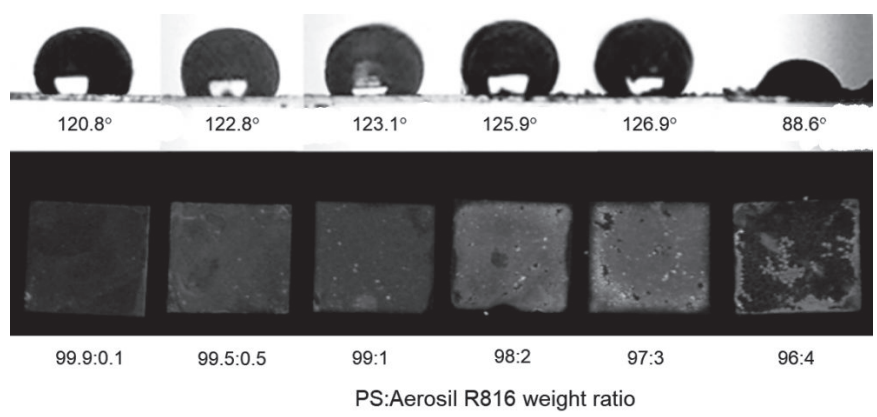

Fig. 3. Measure contact angles (upper) and photos (lower) taken of various PS films incorporated with different amounts of Aerosil R816 (PS/AS3) applied on glass

3. ábra Nedvesitési szög (felső sor) és a hozzájuk tartozó minták amelyekre különbözö mennyiségü Aerosil R816 (PS/AS3) bevonatot vittek fel (alsó sor)

Fig. 4 showed PS coatings (left) filled with Aerosil R 816 (PS/AS3) at varying ratios: 99.5:0.5 and 99.9:0.1. The other two (right) correspond to glass slides coated with PS only and uncoated glass, respectively. Water droplets (colored) are applied on the surfaces to compare non-wetting behavior. Though not as clear as the unfilled PS coating, PS-filled with silica nanoparticles solution-casted using D-limonene as solvent can result in more hydrophobic coatings where optical property can be fine-tuned by changing the silica concentration. 


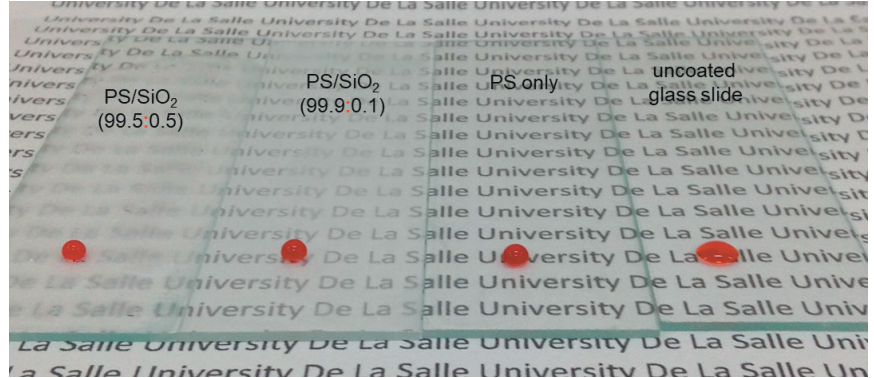

Fig. 4. PS films incorporated with different amounts of Aerosil R816 (PS/AS3) applied on glass compared to just bare PS coating and uncoated glass slide

4. ábra Különbözö mennyiségü Aerosil R816 (PS / AS3) bevonattal ellátott PS-fóliák összehasonlítva tiszta PS bevonattal és bevonat nélküli üveggel

To check on the uniformity of the prepared film from the solution casting of PS filled with Aerosil R816 (PS/AS3), at 99.9:0.1 weight ratio with $\mathrm{D}$-limonene as the dispersing medium, water droplets were placed at various places across the films. As shown in Fig. 5, uniform water droplets can be observed displaying high contact angles, that were previously determined to have an average value of $120.8^{\circ}$ (as opposed to the contact angle observed in PS only, $\left.67.0^{\circ}\right)$.
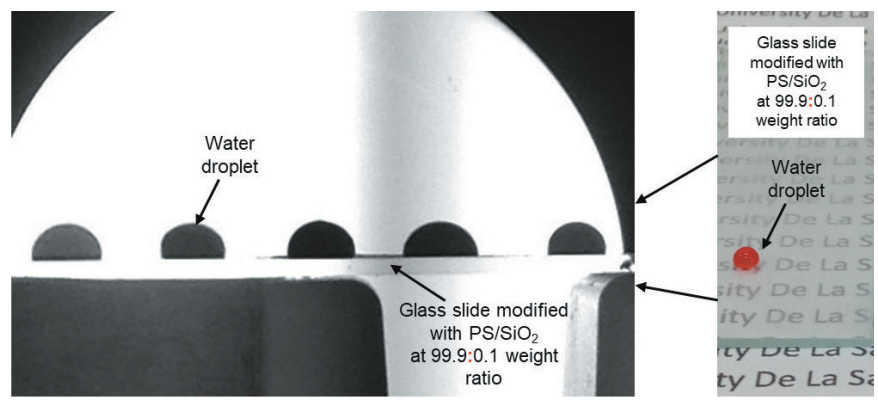

Fig. 5. Deposited water droplets deposited on the surface of PS:Aerosil R816 (PS/ AS3) film (at 99.9:0.1 weight ratio) solution casted from D-limonene as solvent

5. ábra A PS: Aerosil R816 (PS / AS3) film (99,9: 0,1 tömegarányú) felületére helyezett vízcseppek

\section{Conclusions}

In summary, we were able to prepare a highly hydrophobic PSbased coating filled with organo-modified nanosilica particles from solution-casting using $\mathrm{D}$-limonene as the dispersing medium. The film's properties such as non-wetting behavior, film-formation characteristic and optical property can be fine tuned with the type of organo-modified silica particles to be added as well as the silica concentration. From the three commercially available silica nanoparticles used: Aerosil R $812 \mathrm{~S}$, Aerosil R 816, and Aerosil R 972 which are silica nanoparticles chemically pre-modified with hexamethyldisilazane, hexadecylsilane, and dimethyldichlorosilane, respectively - the PS films modified with Aerosil R 816 at 0.1:99.9 weight ratio (relative to PS) result in homogeneous, highly hydrophobic $\left(120.8^{\circ}\right)$ coatings as contrasted to PS only $\left(67.0^{\circ}\right)$.

\section{Acknowledgment}

The authors would like to thank D\&L Industries, Inc. for the technical and chemical assistance extended to carry out this study.

\section{References}

[1] Mohamed, A. M. A. - Abdullah, A. M., \& Younan, N. A. (2015): Corrosion behavior of superhydrophobic surfaces: A review. Arabian Journal of Chemistry, Vol. 8, No. 6, pp. 749-765. https://doi.org/10.1016/j.arabjc.2014.03.006

[2] Zhan-Fang, C. - Pei, Q. - Pei, C. - Xin, W. - Guang-Yi, L., Shuai, W., Hong, Z. (2017): Super-hydrophobic coating used in corrosion protection of metal material: review, discussion and prospects. Metallurgical Research \& Technology, Vol. 114, No. 203, https://doi.org/10.1051/metal/2017011

[3] Syafiq, A. - Vengadaesvaran, B. - Pandey, A. K. - Rahim, N. A. (2018): Superhydrophilic smart coating for self-cleaning application on glass substrate. Journal of Nanomaterials, 2018, Vol. 2018, No. 6412601, pp. 1-10. https://doi.org/10.1155/2018/6412601

[4] Xue, C.-H. - Bai, X. - Jia, S.-T. (2016): Robust, self-healing superhydrophobic fabrics prepared by one-step coating of PDMS and octadecylamine. Scientific Reports, Vol. 6, No. 1. https://doi.org/10.1038/srep27262

[5] Cooksey, K. E. - Wigglesworth-Cooksey, B. (1992): The design of antifouling surfaces: background and some approaches. Biofilms Science and Technology, pp. 529-549.

https://doi.org/10.1007/978-94-011-1824-8_47

[6] Cao, S. - Wang, J. - Chen, H. - Chen, D. (2010): Progress of marine biofouling and antifouling technologies. Chinese Science Bulletin, Vol. 56, No. 7, pp. 598-612. https://doi.org/10.1007/s11434-010-4158-4

[7] Morita, K. - Sakaue, H. (2015): Characterization method of hydrophobic anti-icing coatings. Review of Scientific Instruments, Vol. 86, No. 11, pp. 86-91. https://doi.org/10.1063/1.4935585

[8] Susoff, M. - Siegmann, K. - Pfaffenroth, C. - Hirayama, M. (2013): Evaluation of icephobic coatings - screening of different coatings and influence of roughness. Applied Surface Science, Vol. 282, pp. 870-879. https://doi.org/10.1016/j.apsusc.2013.06.073

[9] Marmur, A. (2003): Wetting on hydrophobic rough surfaces: to be heterogeneous or not to be? Langmuir, Vol. 19, No. 20, pp. 8343-8348. https://doi.org/10.1021/la0344682

[10] Berruezo, M. - Ludueña, L. - Rodriguez, E. - Alvarez, V. (2013): Preparation and characterization of polystyrene/starch blends for packaging applications. Journal of Plastic Film \& Sheeting, Vol. 30, No. 2, pp. 141161. https://doi.org/10.1177/8756087913504581

[11] Andrady, A. L. - Neal, M. A. (2009): Applications and societal benefits of plastics. Philosophical Transactions of the Royal Society B: Biological Sciences, Vol. 364, No. 1526, pp. 1977-1984.

https://doi.org/10.1098/rstb.2008.0304

[12] Lickly, T. D. - Lehr, K. M. - Welsh, G. C. (1995): Migration of styrene from polystyrene foam food-contact articles. Food and Chemical Toxicology, Vol. 33, No. 6, pp. 475-481. https://doi.org/10.1016/0278-6915(95)00009-q

[13] Wang, W. - Shi, S. - Liu, Y. - Wang, G. (2017): The application of expanded polystyrene cushion layer in oblique flexible net systems for rockfall protection: A new attempt. International Journal of Protective Structures, Vol. 9, No. 2, pp. 141-156. https://doi.org/10.1177/2041419617719295

[14] Otake, Y., Kobayashi, T. - Asabe, H. - Murakami, N. - Ono, K. (1995): Biodegradation of low-density polyethylene, polystyrene, polyvinyl chloride, and urea formaldehyde resin buried under soil for over 32 years. Journal of Applied Polymer Science, Vol. 56, No. 13, pp. 1789 1796. https://doi.org/10.1002/app.1995.070561309

[15] Hearon, K. - Nash, L. D. - Rodriguez, J. N. - Lonnecker, A. T. - Raymond, J. E. - Wilson, T. S. - Maitland, D. J. (2014): Recycling: a high-performance recycling solution for polystyrene achieved by the synthesis of renewable poly(thioether) networks derived from d-limonene Advanced Materials, Vol. 26, No. 10, pp. 1551-1551. https://doi.org/10.1002/adma.201470065

[16] Noguchi, T., Miyashita, M. - Inagaki, Y. - Watanabe, H. (1998): A new recycling system for expanded polystyrene using a natural solvent. Part 1. A new recycling technique. Packaging Technology and Science, Vol. 11, No. 1, pp. 19-27.

https://doi.org/10.1002/(sici)1099-1522(199802)11:1<19::aid-pts414>3.0.c0;2-5

[17] García, M. T. - Duque, G., Gracia, I. - de Lucas, A. - Rodríguez, J. F. (2009): Recycling extruded polystyrene by dissolution with suitable solvents. Journal of Material Cycles and Waste Management, Vol. 11, No. 1, pp. 2-5. https://doi.org/10.1007/s10163-008-0210-8 
[18] Maharana, T. - Negi, Y. S. - Mohanty, B. (2007): Recycling of polystyrene Polymer-Plastics Technology and Engineering, Vol. 46, No. 7, pp. 729-736. https://doi.org/10.1080/03602550701273963

[19] Yuan, Z., Chen, H., Tang, J., Chen, X., Zhao, D., \& Wang, Z. (2007). Facile method to fabricate stable superhydrophobic polystyrene surface by adding ethanol. Surface and Coatings Technology, Vol. 201, No. 16-17, pp. 7138-7142. https://doi.org/10.1016/j.surfcoat.2007.01.021

[20] Gupta, T. K. - Kumar, S. (2018): Fabrication of carbon nanotube/polymer nanocomposites. In Carbon Nanotube-reinforced Polymers, pp. 6181. https://doi.org/10.1016/b978-0-323-48221-9.00004-2

[21] Rouabah, F. - Dadache, D. - Haddaoui, N. (2012): Thermophysical and mechanical properties of polystyrene: influence of free quenching. ISRN Polymer Science, Vol. 2012, pp. 1-8. https://doi.org/10.5402/2012/161364

[22] Kim, S. C. (2010): Effect of molecular weight of polymer matrix on the dispersion of MWNTs in HDPE/MWNT and PC/MWNT composites. Macromolecular Research, Vol. 18, No. 5, pp. 512-518. https://doi.org/10.1007/s13233-010-0510-4

[23] Sun, J. (2007). D-limonene: safety and clinical applications. Alternative Medicine Review, Vol. 12, No. 3, pp. 259-264.

[24] Stalder, A. F. - Melchior, T. - Müller, M. - Sage, D. - Blu, T. - Unser, M. (2010): Low-bond axisymmetric drop shape analysis for surface tension and contact angle measurements of sessile drops. Colloids and Surfaces A: Physicochemical and Engineering Aspects, Vol. 364, No. 1-3, pp. 72-81. https://doi.org/10.1016/j.colsurfa.2010.04.040

[25] Yang, J. - Yu, K. - Zuo, Y. Y. (2017): Accuracy of axisymmetric drop shape analysis in determining surface and interfacial tensions. Langmuir, Vol. 33, No. 36, pp. 8914-8923. https://doi.org/10.1021/acs.langmuir.7b01778

[26] Thukkaram, M. - Sitaram, S. - Subbiahdoss, G. (2014). Antibacterial efficacy of iron-oxide nanoparticles against biofilms on different biomaterial Surfaces. International JSournal of Biomaterials, Vol. 2014, Article ID 716080, pp. 1-6. https://doi.org/10.1155/2014/716080

\section{$\underline{\text { Ref.: }}$}

Regalado, Roderick Jesus Jude M. - Punzalan, Emmanuel A. - Penaloza, David P. Jr.: One-pot preparation of PS/silica hydrophobic coating by solution-casting using D-limonene as dispersing medium

Építőanyag - Journal of Silicate Based and Composite Materials, Vol. 71, No. 3 (2019), 80-83. p.

https://doi.org/10.14382/epitoanyag-jsbcm.2019.14

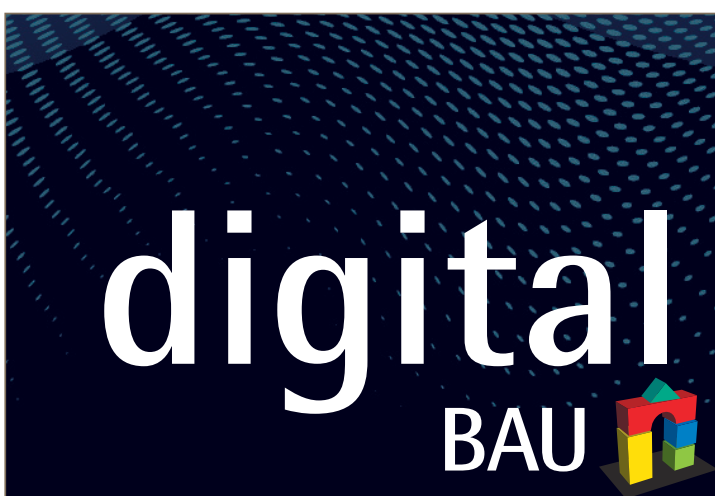

February 11-13, $2020 \cdot$ Cologne

\section{A FORWARD-LOOKING MEETING PLACE FOR THE CONSTRUCTION SECTOR}

\section{- Interest shown by exhibitors exceeds expectations}

- Focus on planning, constructing and operating buildings digitally

- Supporting program with congress and forums

With a three-day trade fair, digitalBAU will bridge the gap between technology and industry. Through the event, the organizers, Messe München and Bundesverband Bausoftware e.V. (BVBS), are responding to the great demand for a platform for digital products and solutions in the construction sector. In addition to renowned exhibitors from the construction software sector, the construction industry and business, there will be a varied supporting program.

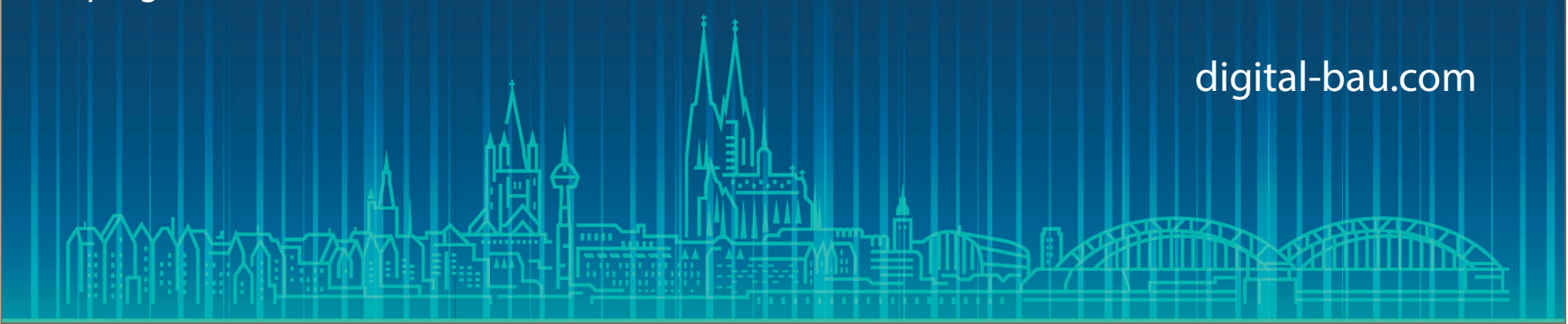

